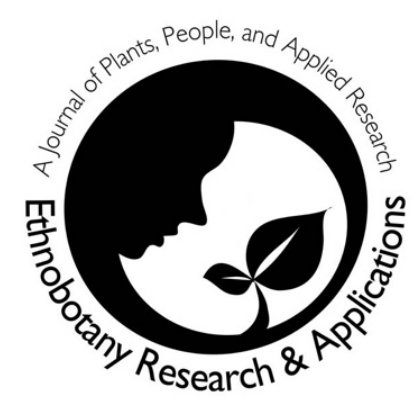

\title{
Between tradition and modernity: the relationship among healers and medicinal plants in an urban center in southern Brazil
}

Camila Fabiana da Silva, Sofia Zank

\author{
Correspondence \\ Camila Fabiana da Silva ${ }^{1}$, Sofia Zank ${ }^{2 *}$ \\ ${ }^{1}$ Center for Biological Sciences, Federal University of Santa Catarina, Florianópolis, Santa Catarina, Brazil. \\ 2Laboratory of Human Ecology and Ethnobotany, Federal University of Santa Catarina, Florianópolis, Santa Catarina, \\ Brazil. Municipal Faculty of Palhoça, Palhoça, Santa Catarina, Brazil \\ *Corresponding Author: sofiazank@gmail.com \\ Ethnobotany Research and Applications 23:2 (2022)
}

\section{Research}

\begin{abstract}
Background. Blessing (or benzedura) is a traditional health practice present in both rural and urban areas of Brazil. Several ethnobotanical studies demonstrate that practitioners have a vast knowledge of medicinal plants; however, it is still necessary to expand research to include the importance of the practice and the ways knowledge is transmitted when facing modernity. Thus, this study was conducted in an urban region of Florianopolis (SC) where we sought to investigate the diseases treated by blessings, the plants used in this practice, and the process of cultural transmission.
\end{abstract}

Methods. We conducted interviews with eleven healers from the eastern region of Florianopolis. Information was collected through semi-structured protocols with a free list of plants, and the botanical collection and identification of mentioned plants. Data was analyzed using descriptive statistics.

Results. A total of 34 types of diseases and ailments that are treated through blessings were cited. For the treatment and cure of these ailments, the use of 24 species of medicinal plants was recorded, the most cited were Ruta graveolens (6 citations), Rosmarinus officinalis (3) and Petiveria alliacea (3). In terms of knowledge transmission, most respondents (46\%) learned in childhood, 36\% learned in adulthood through course, and $18 \%$ learned in adolescence. During the interviews, we noticed that new ways of transmitting knowledge are emerging, where courses and mobile applications are gaining importance.

Conclusions. The practice of blessing continues to play an important role in the health of communities in the eastern region of Santa Catarina Island, and it is undergoing modernizing adaptations. It is important that future studies investigate the effect of technologies on this practice and the possible implications for the resilience or vulnerability of these health systems.

Keywords. Blessings, ethnobotany, health practices, local ecological knowledge, medicinal plants. 


\section{Background}

Blessing is a traditional health practice performed mainly by healers who are present in both remote rural areas (Geleski 2014, Zank \& Hanazaki 2016), as well as urban centers (Soares 2001). The healers make use of prayers, objects, and medicinal plants to cure physical or spiritual illnesses (Clarindo et al. 2019, Maciel \& Neto 2006, Sousa et al. 2021, Zank \& Hanazaki 2016), and faith, according to practitioners, is an indispensable factor for blessings to be effective (Magalhães 2004, Sousa et al. 2021, Zank \& Hanazaki 2016).

Healers have extensive knowledge on the use of medicinal plants (Amorozo 1999, Ávila 2012, Sousa et al. 2021, Zank \& Hanazaki 2016), which are used in massages, teas, baths, and home remedies (Oliveira 1985). In addition to the knowledge of medicinal plant properties, practitioners also believe in their spiritual power (Dias 2009, SiudaAmbroziak 2018) and use several species in their blessings, believing that together they exert greater healing power to the patients (Fonseca-Kruel \& Peixoto 2004).

The practice of blessing arose from the exchange of knowledge between Indigenous, African, and European peoples in the colonization process in Brazil, and for a long time it was one of the main forms of basic health care for the Brazilian population (Geleski 2014, Zank \& Hanazaki 2016). From the 1970s onwards, with the process of modernization and urbanization, and with the advancement of modern medicine and easier access to its resources, the practice of blessing ceased to have a central role in health care, but it has remained throughout time, often complementing modern medicine (Siuda-Ambroziak 2018, Sousa et al. 2021, Zank \& Hanazaki 2017). In recent decades, healers have become more valuable, mainly a reflection of the struggle of traditional Brazilian peoples that has ensured the inclusion of this faith healing in public health policies, including primary care in some municipalities (Almeida 2012).

In the Island of Santa Catarina, in Florianopolis city (Santa Catarina, Brazil), blessing is still widely practiced and is important in local health and culture (Dias 2013, Geleski 2014). Since it is a capital with urban development, the effects of modernity have influenced this practice. Some studies have shown the perception of loss of value and the threat to maintaining the blessing practice (Hoffman-Horochovski 2012, Siuda-Ambroziak 2018). Thus, it is important to investigate this practice in the ethnobotanical scope in order to systematize the knowledge and use of medicinal plants and investigate the cultural transmission, which has not yet been carried out in the region. This information is essential for understanding the current role of blessings in the health of communities and in the proposal of actions and policies that appreciate and maintain this practice, even when facing modernization.

The cultural transmission of traditional knowledge occurs mainly in three forms: vertical - when transmission is between individuals of different generations but within genealogy; horizontal - when transmission is between members of the same generation; and oblique - when transmission occurs between genealogical lines (older generation without kinship) (Cavalli-Sforza et al. 1982; Lozada et al. 2006). Vertical transmission occurs from "one to few" or "few to few" and is considered the most conservative manner of transmission, as it produces moderate rates of change (Cavalli-Sforza et al. 1982). Horizontal and oblique transmission can also occur from "one to many", such as student-teachers or social leaders, which can increase homogeneity within a population (Cavalli-Sforza et al. 1982). Studies on medicinal plant knowledge have demonstrated that the transmission route of medicinal plant knowledge is mainly vertical (Lozada et al. 2006, Santoro et al., 2020), as well as knowledge of blessing practices (Zank \& Hanazaki, 2016).

Within this context, we investigated the practice of blessing in the eastern region of the Island of Santa Catarina (Florianopolis, SC, Brazil), focusing on the use of medicinal plants and cultural transmission of knowledge. The eastern region of the island is one of the oldest in the city, and it is known for its ease in finding healers (Dias 2013). Thus, we seek to answer the following questions in this article: a) what are the diseases treated by blessings? b) What are the most important plants and how are they used? c) How does cultural transmission take place in blessing practices? Lastly, we reflect on the effect of urbanization and modernization in maintaining this traditional practice.

\section{Materials and Methods Study Area}

The study was carried out on the island of Santa Catarina (between the geographic coordinates of $27^{\circ} 22^{\prime}$ and $27^{\circ} 50^{\prime}$ south latitude and $48^{\circ} 25^{\prime}$ and $48^{\circ} 35^{\prime}$ west longitude), in the city of Florianopolis, state of Santa Catarina, southern Brazil. It has an area of $675,409 \mathrm{~km}^{2}$, and its current population is around 421,240 inhabitants (IBGE 2010). The 
climate type is $\mathrm{Cfa}$ (humid mesothermal, with hot summers and rain distributed throughout the year). The predominant form of relief is mountainous with altimetric amplitudes exceeding 300 meters and slopes with different degrees of inclination. The island has two main vegetation types in different successional stages: dense rainforest and coastal vegetation, which includes mangroves and restingas (sand dune vegetation) (Klein 1978).

The eastern region, where this study was conducted, has 23,287 inhabitants (IBGE 2010) and includes the neighborhoods Lagoa da Conceição, Ponta das Almas, Canto dos Araçás, Canto da Lagoa, Costa da Lagoa, Retiro, Joaquina, Fortaleza da Barra da Lagoa, Barra da Lagoa, and São João do Rio Vermelho. We selected these neighborhoods for the study because the practice of blessings is still a part of popular culture (Geleski 2014), despite the city's modernization, and is a supposedly easy place to find healers, as they are well known by the residents of the community (Dias 2013).

The local communities have strong characteristics of Azorean culture, such as bobbin lacemakers, which began to appear in the $18^{\text {th }}$ century with European colonization (Silva 2016). Until the 1970s, agriculture and fishing were the main economic activities. However, with the city's rapid growth in recent decades, its economy is based mainly on the provision of public services, commerce, industry, and tourism (Silva 2016).

\section{Methods}

Data collection

The identification of healers present in each neighborhood in the eastern region of the Island of Santa Catarina was conducted using the "snowball" methodology (Bernard 2005). The initial identification began with a doctor from the Public Health Service, who had already worked at health posts in the region and knew local healers. Additionally, at each interview, participants were encouraged to indicate the names of other healers in the region. The snowball was finished when there were no further indications.

To collect information, semi-structured interviews were used, with a free list of plants, and the collection and identification of mentioned plants. The interview script contained questions about socioeconomic data (name, gender, age, occupation), the types of diseases (therapeutic targets) that are treated with blessings (What types of diseases do you treat with healing? Name of the disease, description, and materials used), the prayers and plants used (Which of them use medicinal plants? Free list with plant name and form of use), and the way in which this knowledge is transmitted (With whom did you learn to bless? Do you exchange knowledge of prayers and plants with other healers?). Data collection was conducted from July to August 2018 and involved at least 2 visits to each of the interviewees.

Botanical material

Using standard procedures for ethnobotanical collections (Cunningham 2001), the plants mentioned, when available in the backyard of the healers, were collected for identification, mounted, and taken to the laboratory of Didactic Garden of Medicinal Plants located in the University Hospital of the Federal University of Santa Catarina. The plants were identified through specific bibliographies and with the help of specialists, based on the botanical material collected and on photographs. Since the plants mentioned in this study are common and not fertile, it was not possible to deposit them in the institution's herbarium. The nomenclature and families names were verified in the Plants of the World Online database (http://powo.science.kew.org/) of Royal Botanic Gardens, Kew.

Data analysis

Information from the interviews was tabulated and analyzed using descriptive statistics. Only medicinal plants related to the treatment of disease through the practice of blessings were considered. The form of knowledge transmission was categorized according to Cavalli-Sforza et al. (1982) and Lozada et al. (2006) into three categories: 1) vertical transmission, when participants reported having learned from their parents or grandparents; 2 ) horizontal transmission - when they reported having learned from people of the same generation; and 3) oblique transmission - when they reported having learned from people of other generations without family ties. We also classified the stage of life in which learning took place: A) childhood (up to 11 years old); B) adolescence (from 12 to 20 years old); C) adulthood (from 21 years old). This classification followed national documents - Child and Adolescent Statute (Brasil 1990).

During the interviews, learning through courses emerged, and as much as courses are considered a form of oblique transmission, in the form of "one to many," we chose to leave it as a separate category, since this form of 
transmission is not common in the scope of blessings (Zank \& Hanazaki 2016), and we want to emphasize this innovation.

\section{The healers of eastern Santa Catarina Island}

We identified fifteen healers in the study region, and of these, eleven agreed to collaborate with the research. Four healers did not accept to participate, two due to health problems, one was traveling out of town, and one did not want to participate. Of the healers interviewed, most live in the Rio Vermelho neighborhood (eight), and the others in the neighborhoods Barra da Lagoa, Lagoa da Conceição, and Costa da Lagoa.

Throughout the research we came across two groups of healers, which were classified as proposed by Gill (2010): 1) Traditional healers, who are the oldest healers, and, in general, they learned the blessings through family, friends, and/or neighbors, and 2) Religious healers, which refers to faith healers who learned healing techniques in terreiros (spaces of Afro-Brazilian religions).

Five healers were identified as traditional and six were religious, all the religious healers live in the Rio Vermelho neighborhood. The traditional healers are practitioners of the Catholic religion and one of them also attends a spiritual center. On the other hand, all religious healers are practitioners of the Umbanda religion (religion of African origin). The healers of both groups are usually devotees of Catholic saints, usually having images in their homes and some of them have resources for spiritual uses, such as saint medallions and crucifixes, demonstrating the existence of a religious syncretism associated with this practice.

In total, we interviewed ten female and one male healer, which demonstrates blessings as a practice commonly, but not exclusively, performed by women. Most of the healers are over 60 years old $(54.5 \%)$, which demonstrates the influence of older women in the practice of blessings.

The other healers are aged between 30 and 59 years (36.4\%), and although the practice of healers is usually characterized by older women, a 19-year-old healer was also registered.

In terms of the healer's occupation, we found that all traditional healers are retired, and this is related to their age, which is over 60 years old. The religious healers said they were students (two in higher education and one in high school), artisan, massage therapist, and general service worker.

\section{Results}

\section{Diseases treated by blessings}

We identified a total of 34 types of illnesses and ailments treated through blessings, whose descriptions can be found in Table 1. Of these, the majority (25) are directly related to physical problems in the body and can be associated with symptoms diagnosed and also treated by modern medicine, such as erysipelas, contusion, or twist (carne quebrada), and general pain (in the head, kidneys, stomach, etc.). Nonetheless, at least nine diseases were mentioned that are more associated with spiritual and energetic issues such as evil eye (mau olhado) or brokenness (quebrante), fright (susto), and bewitching (embruxado).

Eight blessings are practiced by more than two healers, and 26 were mentioned by just one person. In the latter case, the majority refers to a religious blessing healer who performs more than 22 different types of blessings. Most blessings (19) use plants in the healing process. In addition to plants, other objects are also used such as cloths, needles, crucifix, among other materials (Table 1).

Among the diseases with a spiritual or energetic origin, embruxado, caused by an attack from a witch, was only mentioned by one traditional healer, who is the most well known locally. She reported a case of a bewitched child, who was brought to her on the recommendation of a medical doctor in the region who said they could not solve the problem because it was a spiritual illness. When evaluating the child, the healer noticed that there were bites on her tongue caused by a witch and that was where she sucked the child's energy. According to the healer's perception, after praying a few times, the child was healed. 
Table 1. Diseases and illnesses treated by blessings in the eastern region of the Santa Catarina Island, Florianopolis, SC. The description of the diseases/illnesses was compiled from the explanations of the healers themselves. Trad $=$ Traditional healers; Rel $=$ Religious healers.

\begin{tabular}{|c|c|c|c|c|c|}
\hline \multirow[t]{2}{*}{ Diseases/Illnesses } & \multirow[t]{2}{*}{ Description according to healers } & \multirow{2}{*}{$\begin{array}{l}\text { Resources } \\
\text { used }\end{array}$} & \multicolumn{3}{|c|}{ No. of healers $(n=11)$} \\
\hline & & & \begin{tabular}{|l|} 
Trad \\
\end{tabular} & Rel & Total \\
\hline $\begin{array}{l}\text { Brokenness (Quebrante)/ } \\
\text { evil eye (Mal olhado) }\end{array}$ & $\begin{array}{l}\text { When a person is envious of someone } \\
\text { and wants to be like her or have what } \\
\text { she has. The life of the envied person } \\
\text { does not prosper. Occurs in people } \\
\text { and animals. Symptoms in children: } \\
\text { sadness, lack of appetite, malnutrition. }\end{array}$ & $\begin{array}{l}\text { Plant and } \\
\text { crucifix }\end{array}$ & 5 & 4 & 9 \\
\hline $\begin{array}{l}\text { Erysipelas (Erisipela, Zipra, } \\
\text { Zipela, and Zipelão) }\end{array}$ & $\begin{array}{l}\text { Leg problems (from the knee down) } \\
\text { caused by injuries. Symptoms: redness, } \\
\text { inflammation, and pain. }\end{array}$ & $\begin{array}{l}\text { Plant, olive } \\
\text { oil, and } \\
\text { cotton or } \\
\text { sheep wool }\end{array}$ & 5 & 2 & 7 \\
\hline $\begin{array}{l}\text { Twist (Carne quebrada, } \\
\text { Cosê, Costura, Osso } \\
\text { rendido) }\end{array}$ & $\begin{array}{l}\text { When there is a twisting of any part of } \\
\text { the body, such as the foot or hand, } \\
\text { which causes dislocation, swelling, } \\
\text { muscle pain, or inflammation of the } \\
\text { nerve. Also characterized by cuts and } \\
\text { bruises. }\end{array}$ & $\begin{array}{l}\text { Cloth, } \\
\text { needle, and } \\
\text { oil }\end{array}$ & 2 & 3 & 5 \\
\hline $\begin{array}{l}\text { Fallen stickleback } \\
\text { (Espinhela caída) and } \\
\text { fallen ark (arcacaída) }\end{array}$ & $\begin{array}{l}\text { Dislocation of the ribs that occurs } \\
\text { mainly in children. Symptoms: back } \\
\text { pain, chest pain, and breathing } \\
\text { difficulties. }\end{array}$ & Massage & 1 & 2 & 3 \\
\hline Fright & $\begin{array}{l}\text { When the person is frightened and is } \\
\text { "scared," it is more common in } \\
\text { children. Symptoms: difficulty sleeping } \\
\text { and may have diarrhea and vomiting. }\end{array}$ & $\begin{array}{l}\text { Child's left } \\
\text { shoe }\end{array}$ & 2 & 1 & 3 \\
\hline Shingles (Cobreiro) & $\begin{array}{l}\text { Specific allergy caused by bugs that } \\
\text { pass on a person's skin or clothing. } \\
\text { Symptom: white patches on the skin } \\
\text { that form water bubbles. }\end{array}$ & $\begin{array}{l}\text { Plant and } \\
\text { chain with } \\
\text { St. Peter }\end{array}$ & - & 3 & 3 \\
\hline $\begin{array}{l}\text { Sun on the head, } \\
\text { Insolation }\end{array}$ & $\begin{array}{l}\text { Headache caused by excessive } \\
\text { exposure to the sun. }\end{array}$ & $\begin{array}{l}\text { Clear glass } \\
\text { bottle and } \\
\text { cloth }\end{array}$ & 1 & 1 & 2 \\
\hline $\begin{array}{l}\text { Clothes conjuring } \\
\text { (Conjuro de roupas) }\end{array}$ & $\begin{array}{l}\text { Problems in general sadness, rebellion, } \\
\text { discouragement, depression. They pray } \\
\text { with a personal object of the person, } \\
\text { such as a photo or a piece of clothing. }\end{array}$ & $\begin{array}{ll}\text { Pieces } & \text { of } \\
\text { clothing } & \text { or } \\
\text { photo } & \end{array}$ & - & 2 & 2 \\
\hline Bewitching (Embruxado) & $\begin{array}{l}\text { Caused by an attack from witches, } \\
\text { especially in children. Symptoms: } \\
\text { weakness, lack of appetite, insomnia. }\end{array}$ & Plant & 1 & - & 1 \\
\hline Yellowing (Amarelão) & $\begin{array}{l}\text { A disease caused by worms that cause } \\
\text { diarrhea, stomach pains, and yellowish } \\
\text { skin. }\end{array}$ & Plant & - & 1 & 1 \\
\hline Screwworm in animals & Wound with parasites & - & - & 1 & 1 \\
\hline $\begin{array}{l}\text { Overturned stomach } \\
\text { (Bucho virado) }\end{array}$ & Digestive problems in children & & & 1 & 1 \\
\hline Mumps & $\begin{array}{l}\text { Disease that appears behind the ear, } \\
\text { more common in children. Symptoms: } \\
\text { inflammation, fever, pain, and lack of } \\
\text { appetite. }\end{array}$ & Plant & 1 & - & 1 \\
\hline Constipation & Constipation & Plant & - & 1 & 1 \\
\hline Cravo & Warts that appear on the body & - & 1 & - & 1 \\
\hline Stomachache & $\begin{array}{l}\text { Caused by poor digestion or } \\
\text { gas }\end{array}$ & Plant & - & 1 & 1 \\
\hline Headache & In general & - & - & 1 & 1 \\
\hline Localized pain & In general & Plant & - & 1 & 1 \\
\hline Fever & $\begin{array}{l}\text { Caused by various reasons, such as } \\
\text { severe flu. }\end{array}$ & Plant & - & 1 & 1 \\
\hline $\begin{array}{l}\text { Angry wound (ferida } \\
\text { brava) }\end{array}$ & Wound in people with diabetes & - & - & 1 & 1 \\
\hline Herpes & $\begin{array}{l}\text { Infection that affects the lips, occurs } \\
\text { mainly in adults. }\end{array}$ & Plant & - & 1 & 1 \\
\hline Infection & In general & Plant & - & 1 & 1 \\
\hline
\end{tabular}




\begin{tabular}{|l|l|l|l|l|l|}
\hline Inflammation & In general & Plant & - & 1 & 1 \\
\hline 7-day illness & Old disease that led a child to death. & - & - & 1 & 1 \\
\hline Urine illness & Urinary problems, such as infections & - & - & 1 & 1 \\
\hline Eyes & Conjunctivitis & Plant & - & 1 & 1 \\
\hline Parasites in animals & $\begin{array}{l}\text { Diseases caused by worms that cause } \\
\text { malnutrition and weakness in animals }\end{array}$ & Red ribbon & - & 1 & 1 \\
\hline Rheumatism & General body pain & Plant & 1 & - & 1 \\
\hline Kidney pain & Kidney pain & Plant & - & 1 & 1 \\
\hline $\begin{array}{l}\text { Open a path (Abrir } \\
\text { caminho) }\end{array}$ & Dispel various problems & Plant & - & 1 & 1 \\
\hline Assistance from distance & $\begin{array}{l}\text { Any kind of problem - prayers done at } \\
\text { a distance }\end{array}$ & Plant & - & 1 & 1 \\
\hline Prosperity in commerce & $\begin{array}{l}\text { For people to think positively about } \\
\text { their business }\end{array}$ & - & - & 1 & 1 \\
\hline Grounded (De chão) & To prosper in life & - & - & 1 & 1 \\
\hline Energetic cleaning & $\begin{array}{l}\text { Some health problems are caused by } \\
\text { pollution of a person's energy field. }\end{array}$ & Plant & & 1 & 1 \\
\hline
\end{tabular}

\section{Plants used in blessings}

We recorded 24 species of medicinal plants used by healers, with an average citation of 3.9 (sd=4.4). The most cited plants by healers were Ruta graveolens (6), Rosmarinus officinalis (3), Petiveria alliacea (3), Sansevieria trifasciata (3), Alternanthera brasiliana (3), Solidago chilensis (2), Citrus spp.1 (2), Bidens pilosa (2), and Coriandrum sativum (2) (Table 2). The other plants were mentioned only once.

Of the use citations, $53.5 \%$ are used during prayer, $27.9 \%$ are used in baths, and $18.6 \%$ are used for teas. The healers believe that plants have the ability to undo spiritual and physical problems, and that is why they use them to perform the prayers of the blessings. The choice of plant to use in prayer depends on the level of the problem, the spiritual power of plants, and on the affinity between the healer and certain herbs (e.g. the healer usually prays with a specific plant).

Table 2. Medicinal plants used in the practice of blessing in the eastern region of the Santa Catarina Island, Florianopolis, SC.

\begin{tabular}{|c|c|c|c|c|c|}
\hline Scientific identification & $\begin{array}{l}\text { Common } \\
\text { Name }\end{array}$ & $\begin{array}{l}\text { No. of } \\
\text { citations }\end{array}$ & $\begin{array}{l}\text { Diseases/ } \\
\text { illnesses treated }\end{array}$ & $\begin{array}{l}\text { Form of } \\
\text { use }\end{array}$ & $\begin{array}{l}\text { Collector number } \\
\text { or photo- } \\
\text { identification }\end{array}$ \\
\hline \multicolumn{6}{|l|}{ Acanthaceae } \\
\hline $\begin{array}{l}\text { Justicia gendarussa Burm. } \\
\text { f. }\end{array}$ & $\begin{array}{l}\text { Abre- } \\
\text { caminho }\end{array}$ & 1 & Abrir caminho (1) & Prayer (1) & Photo \\
\hline \multicolumn{6}{|l|}{ Amaranthaceae } \\
\hline $\begin{array}{l}\text { Alternanthera brasiliana } \\
\text { (L.) Kuntze }\end{array}$ & Penicilina & 3 & $\begin{array}{l}\text { Infections (2), } \\
\text { Erysipelas (1) }\end{array}$ & $\begin{array}{l}\text { Tea }(2), \\
\text { prayer }(1)\end{array}$ & CS 04 \\
\hline \multicolumn{6}{|l|}{ Anacardiaceae } \\
\hline Mangifera indica $\mathrm{L}$. & Mangueira & 1 & $\begin{array}{l}\text { Energy cleansing } \\
\text { (1) }\end{array}$ & Prayer (1) & - \\
\hline \multicolumn{6}{|l|}{ Apiaceae } \\
\hline Coriandrum sativum $\mathrm{L}$. & Coentro & 2 & Inflammation (2) & $\begin{array}{l}\text { Prayer (1), } \\
\text { bath (1) }\end{array}$ & Photo \\
\hline Foeniculum vulgare Mill. & Funcho & 1 & Rheumatism (1) & Tea (1) & CS 06 \\
\hline Pimpinella anisum $\mathrm{L}$. & Erva-doce & 1 & Rheumatism (1) & Tea (1) & CS 03 \\
\hline \multicolumn{6}{|l|}{ Aristolochiaceae } \\
\hline $\begin{array}{l}\text { Aristolochia triangularis } \\
\text { Cham }\end{array}$ & $\begin{array}{l}\text { Cipó-mil- } \\
\text { homens }\end{array}$ & 1 & Erysipelas (1) & Tea (1) & - \\
\hline \multicolumn{6}{|l|}{ Asteraceae } \\
\hline Bidens pilosa $L$. & Picão-preto & 2 & Amarelão (2) & $\begin{array}{l}\text { Bath (1), } \\
\text { tea }(1)\end{array}$ & CS 02 \\
\hline Solidago chilensis Meyen & Arnica & 2 & $\begin{array}{l}\text { Contusion/ sprain } \\
\text { (2) }\end{array}$ & $\begin{array}{l}\text { Prayer (1), } \\
\text { bath (1) }\end{array}$ & CS 08 \\
\hline \multicolumn{6}{|l|}{ Boraginaceae } \\
\hline Varronia curassavica Jacq. & Erva-baleeira & 1 & All (1) & Prayer (1) & CS 01 \\
\hline Dracaenaceae & & & & & \\
\hline
\end{tabular}




\begin{tabular}{|c|c|c|c|c|c|}
\hline $\begin{array}{l}\text { Sansevieria trifasciata } \\
\text { Prain }\end{array}$ & $\begin{array}{l}\text { Espada-de- } \\
\text { são jorge }\end{array}$ & 3 & $\begin{array}{l}\text { Embruxado (2), } \\
\text { all (1) }\end{array}$ & $\begin{array}{l}\text { Bath (2), } \\
\text { prayer (1) }\end{array}$ & Photo \\
\hline \multicolumn{6}{|l|}{ Geraniaceae } \\
\hline $\begin{array}{l}\text { Pelargonium graveolens } \\
\text { L'Hér }\end{array}$ & $\begin{array}{l}\text { Malva- } \\
\text { cheirosa }\end{array}$ & 1 & All (1) & Prayer (1) & CS 09 \\
\hline \multicolumn{6}{|l|}{ Lamiaceae } \\
\hline Lavandula sp. & Alfazema & 1 & Embruxado (1) & Bath (1) & Photo \\
\hline $\begin{array}{l}\text { Leonotis nepetifolia (L.) } \\
\text { R.Br. }\end{array}$ & $\begin{array}{l}\text { Cordão-de- } \\
\text { são-francisco }\end{array}$ & 1 & Embruxado (1) & Bath (1) & - \\
\hline Menthasp. & Hortelã & 1 & Stomachache (1) & Tea (1) & Photo \\
\hline Rosmarinus officinalis L. & Alecrim & 3 & $\begin{array}{l}\text { Embruxado (1), } \\
\text { calmative (1), all (1) }\end{array}$ & $\begin{array}{l}\text { Prayer (2), } \\
\text { bath (1) }\end{array}$ & Photo \\
\hline Ocimum americanum $\mathrm{L}$. & Manjericão & 1 & All (1) & Prayer (1) & Photo \\
\hline \multicolumn{6}{|l|}{ Malvaceae } \\
\hline Sida sp. & Guanxuma & 1 & Mumps (1) & Prayer (1) & - \\
\hline \multicolumn{6}{|l|}{ Myrtaceae } \\
\hline Eugenia uniflora L. & Pitanga & 1 & Erysipelas (1) & Bath (1) & Photo \\
\hline \multicolumn{6}{|l|}{ Phytolaccaceae } \\
\hline Petiveria alliacea $L$. & Guiné & 3 & $\begin{array}{l}\text { Quebrante (2), } \\
\text { embruxado (1) }\end{array}$ & $\begin{array}{l}\text { Prayer (2), } \\
\text { bath (1) }\end{array}$ & Photo \\
\hline \multicolumn{6}{|l|}{ Rosaceae } \\
\hline Rosa alba L. & Rosa & 1 & Quebrante (1) & Prayer (1) & Photo \\
\hline \multicolumn{6}{|l|}{ Rutaceae } \\
\hline Citrus spp.1 & Laranjeira & 2 & $\begin{array}{l}\text { Erysipelas (1), all } \\
\text { (1) }\end{array}$ & $\begin{array}{l}\text { Bath (1), } \\
\text { prayer (1) }\end{array}$ & CS 07 \\
\hline Citrus spp. 2 & Limão & 1 & Herpes (1) & Prayer (1) & CS 05 \\
\hline Ruta graveolens L. & Arruda & 6 & $\begin{array}{l}\text { Quebrante (2), } \\
\text { cobreiro (1), } \\
\text { embruxado(1), all } \\
\text { (2) }\end{array}$ & $\begin{array}{l}\text { Prayer (5), } \\
\text { bath (1) }\end{array}$ & Photo \\
\hline
\end{tabular}

\section{Knowledge transmission}

Regarding the way the healers learned to bless, $46 \%$ of the interviewees said they learned it in childhood. Of these, the majority ( $80 \%$ of the $46 \%$ ) began blessing only after the age of 40 , after the death of their mothers. Another $18 \%$ learned during their adolescence, and $36 \%$ learned in adulthood. Of the healers who learned the prayers in childhood, all were through vertical transmission (Figure 1) when they heard their mothers and grandmothers praying to people who sought them out.

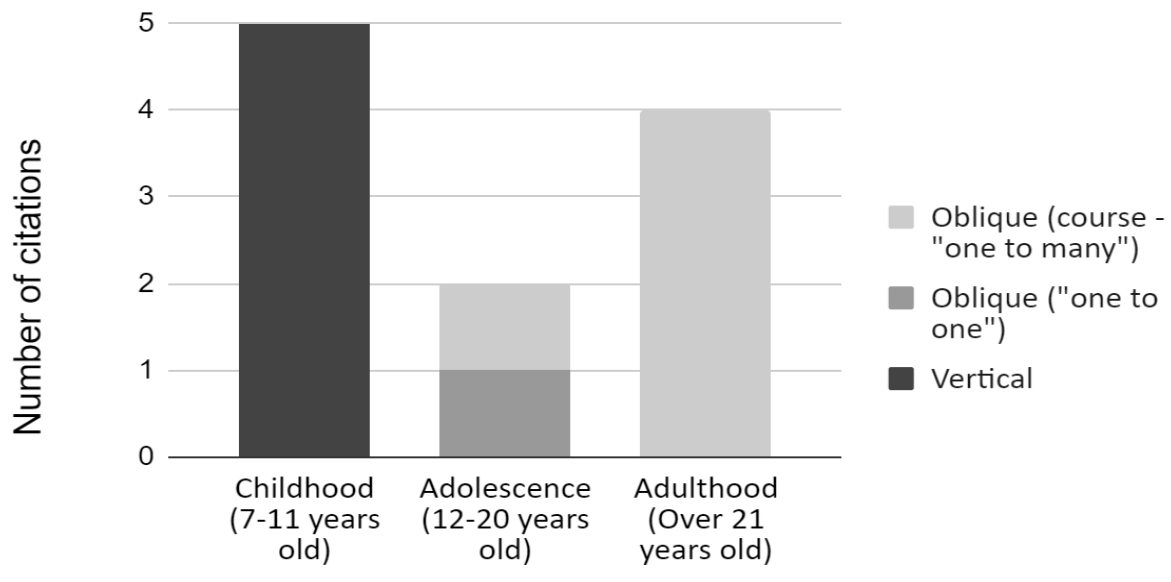

Learning age

Figure 1. Cultural transmission about blessings by healers from eastern Santa Catarina Island, Florianopolis, SC. 
In terms of healers that learned during their adolescence, the two learned through oblique transmission, one by observing community healers who blessed her, and another healer reported having learned in a course (Table 2).

Healers that learned in adulthood, learned through a course (oblique), which is taught by one of the healers we interviewed. They are responsible for conducting training courses for healers at an Afro-Brazilian religion center.

Nevertheless, all the healers said that to bless, the person must have the gift, and that to start practicing blessings, an "awakening" must occur, that is, the person has to realize they have the gift of blessing. This awakening in some situations is related to spiritual experiences, such as visions and dreams about blessing. According to them, at some point in life this awakening will happen and there is not necessarily an ideal age for this to happen.

When asked about the exchange of knowledge about prayers and plants with other healers, the traditional healers stated that they do not usually perform them, as they do not have much contact with other healers. The religious healers, on the other hand, stated that this is a common practice among them, and they all mentioned being part of a closed virtual group on a cell phone application, in which they exchange information about prayers and plants with other healers. When a healer has a question and needs more information about a prayer or about medicinal uses of plants, they put it in the group and those with the information answer the question. This information was not investigated in depth, as it was not an initial focus of this research, but it demonstrates how technologies have allowed the exchange of information without the need for in person meetings between the healers in the study region.

\section{Discussion}

Blessing in the eastern region of Santa Catarina Island is performed mainly by older women, highlighting the importance that women have in this healing practice, as observed in other studies (Boing \& Stancik 2013, Geleski 2014, Maciel \& Neto 2006, Moura 2001, Oliveira 1985, Oliveira \& Trovão 2009, Siuda-Ambroziak 2018, Sousa et al. 2021, Zank \& Hanazaki 2012). Blessings may be connected with women as a result of a historical division of labor where men normally worked outside the home and women were more dedicated to taking care of the day to day life of the home and family, leading them to have greater contact with health care practices and spirituality (Gill 2010).

In this study, we found that blessings are used to treat a wide range of health problems (34), with only eight being performed by more than two healers. The number of health problems cited is much higher than that recorded by Zank and Hanazaki (2016), and Maciel and Neto (2006). The first study recorded 20 health problems treated with blessings through interviews with 41 healers (rezadores) from the Chapada do Araripe (CE, Brazil), and the second study recorded 16 health problems through interviews with four healers in the municipality of Jurema (MT, Brazil). This high number of diseases reflects the importance that this practice plays in primary health care in the communities studied, even in an urbanized region, with easy access to modern medicine. In addition, diseases of spiritual or cultural causes, such as evil eye, brokenness, and embruxado, are not treated by modern medicine and, therefore, blessings and modern medicine usually act in a complementary manner (Zank \& Hanazaki 2016, Zank \& Hanazaki 2017).

The disease embruxado (bewitching) seems to be specific to the Island of Santa Catarina, and it is associated with the ancient and local culture of the Island's witches. There are many stories about witches and healers, which are part of the local folklore associated with Azorean colonization (Maluf 1992). This prayer is performed by only one traditional healer and perhaps it is no longer practiced, since the figure of witches on the island had been changing with modernization. In addition, a large part of diseases treated by healing are carried out by just one person, which brings the risk of these prayers disappearing in the event of the death or change in residence of this healer (Zank \& Hanazaki 2016). In this context, it would be important to encourage the exchange of information and prayers among current healers, which is already happening in the study area among religious blessing healers.

In relation to the plants used, as well as in other studies, some plants are prioritized to perform the prayers, in this case $R$. graveolens, $R$. officinalis, and $P$. alliacea. These same plants were also highlighted in studies with healers (Maciel \& Neto 2006), Zank \& Hanazaki 2016, Oliveira et al. 2018, Clarindo et al. 2019). They are also common in ethnobotanical studies in African-based religions and with other Afro-Brazilian groups (Pagnocca et al. 2020), demonstrating the biocultural importance of these plants within the scope of healing and religious practices. $R$. graveolens and $R$. officinalis are plants of Mediterranean origin, commonly used in Brazil in a ritualistic manner against the evil eye and for protection (Pagnocca et al. 2020), and they are also used because of their medicinal 
properties (Lorenzi \& Matos 2008). P. alliacea is a plant of South American origin, also used medicinally and ritually, but in high doses it is considered toxic and should be used with caution when ingested (Lorenzi \& Matos 2008), which is not a concern in blessings, since it is only used externally.

In addition to prayer, plants for tea and baths are also indicated, which suggests that the treatment goes beyond spiritual issues and is also directly related to physical aspects of the body. This is in line with the holistic perspective of traditional health practices, which involve several aspects, such as the physical, spiritual, emotional, among others (Zank \& Hanazaki 2017).

The use of herbs in baths is closely related to the perception that they have power to "unload" the body and perform spiritual cleansing (Pagnocca et al. 2020, Van Andel et al. 2013). According to the healers, the "charged" body can be caused by "brokenness" (envy, evil eye) or by spiritual attacks from witches or spirits. Baths are also indicated for some physical problems of the body, such as amarelão (yellowing), bruise/sprain, inflammation, colds, and erysipelas. The teas are used as a complementary treatment to prayer, to be made at home by the patients, and are mainly related to physical problems in the body.

Regarding the medicinal plants used, both groups of healers know and use plants for the healing process. The healers have an important role in maintaining and transmitting knowledge about medicinal plants because, in addition to cultivating these in their homes, they are people who have extensive knowledge about their ways of use and are available to teach both to patients and other healers.

Regarding the form of learning and transmission of this knowledge, vertical transmission was predominant in childhood, which was also observed by other researchers (Cavalli-Sforza et al. 1982, Reyes-Garcia et al. 2016). This is possibly because children spend more time with their families, observing and learning through daily practice (Cavalli-Sforza et al. 1982, Reyes-Garcia et al. 2016). On the other hand, the current family dynamics in urban centers has been changing this reality, since today many children and young people stay in day care centers and school full time, and, therefore, spend less time with family members, which can even influence the disinterest in the practices of the elderly.

Moreover, we also observed a predominance of oblique transmission, which in this study is mainly related to the emergence of blessing courses. This demonstrates that oblique transmission is important in the formation of knowledge in adults, as verified by Reyes-Garcia (2016). It provides opportunities for gaining new knowledge that can be adapted and lead to cultural changes over generations, which was also cited in other studies (Cavalli-Sforza et al. 1982, Reyes-Garcia et al. 2016, Soldati 2013, Zank \& Hanazaki 2012). Oblique transmission contributes to the exchange of information that can complement prior knowledge or even replace it (Reyes-Garcia et al. 2016, Santoro et al., 2020).

In terms of the healers' opinions in relation to the courses that have been taught, the religious healers said they thought it was important that they take place to continue this practice. They also believe that it is important for the courses to be recognized and made official, as they can then serve as a political tool to legitimize the act of blessing. Traditional healers, on the other hand, reported not knowing about the existence of blessing courses and when asked about what they think of this form of learning, all considered the existence of courses to be important, as it can contribute to the continuity of the practice.

The results demonstrate that the practice of blessing continues to play an important role in the eastern region of Florianopolis. Associated with this, we also registered the use of technologies in the process of transmitting this knowledge, which may be reflecting a process of necessary adaptation to maintain this practice in current times. We believe that the connection between tradition and modernity can benefit the health of communities, but it's important to investigate the possible implications for the resilience or vulnerability of these health systems. Furthermore, we emphasize the importance of promoting social organization of healers in the city of Florianopolis to strengthen this practice and ensure recognition and the right to perform blessings in formal health spaces, as is already the case in some Brazilian municipalities (Almeida 2012). 


\section{Study limitations}

This research was carried out as graduation course completion work and without financial resources, thus, it was not possible to extend the investigation to other regions of the Island of Santa Catarina. Furthermore, we did not set out to investigate technological innovations in cultural transmission with this study. This was new information that emerged while conducting our study and we chose to address it in the results, in order to encourage further research into this issue.

\section{Conclusion}

The practice of blessings plays an important role in the health care of the investigated communities, even in the face of urbanization and modernization. We recorded several health problems and illnesses treated by blessings, and some prayers are shared by more than one healer. In relation to the use of medicinal plants, the importance that these plants have in this practice is remarkable, both for use in prayers, as well as teas and baths. As much as vertical transmission stood out in this study, oblique transmission also plays an important role in adulthood, mainly associated with courses. The data collected in this study demonstrates the connection between tradition and modernity, as traditional practices continue to maintain their function and are undoing innovations, such as an adaptation process in the face of modernization with the courses and cellphone application to exchange knowledge. Thus, we recommend that future studies be carried out to understand the influence of technologies on traditional health practices.

\section{Declarations}

List of abbreviations: SC - Santa Catarina State; MT - Mato Grosso State

Ethics approval and consent to participate: The development of the study followed the ethical and legal guidelines for the development of research on traditional knowledge. The project was approved by the Ethics Committee for Research with Human Beings of the Federal University of Santa Catarina (CEPSH) under the number: 82427718.0.0000.0121 de 18/06/2018. The participation of healers was subject to the acceptance of the Free and Informed Consent Form. The project was registered with SISGEN under the number A011D4A.

Consent for publication: Not applicable

Availability of data and materials: Not applicable

Competing interests: Not applicable

Funding: Not applicable

Author contributions: C.F.S. collected the data, analyzed, and wrote the text. S.Z. participated in the theoretical background, monitoring data collection and analysis, helping with discussions, and wrote the final version of the text.

\section{Acknowledgements}

We would like to thank each healer who contributed to this research and shared their knowledge. We would like to pay tribute to Rodrigo Castro Ramires, the only male healer, who shared detailed information on the dynamics of blessings within the African-based religion and died a few months after the field research was conducted.

\section{Literature cited}

Almeida AWB. 2012. Conhecimentos Tradicionais e mobilizações políticas: o direito de afirmação da identidade de benzedeiras e benzedores, municípios de Rebouças e São João do Triunfo, Paraná-Manaus. Editora da Universidade do Estado do Amazonas, Brasil.

Amorozo MC. 1999. Medicina Tradicional em Santo Antônio do Leverger-MT: a permanência de práticas antigas e o papel dos benzedores e suas habilidades. Revista Saúde e Ambiente 2:48-66.

Ávila JVC. 2012. Etnobotânica de plantas utilizadas como medicinais pelos benzedores nos municípios de Imbituba e Garopaba-SC-Brasil. Monography, Federal University of Santa Catarina.

Bernard HR. 2005. Research methods in anthropology: qualitative and quantitative approaches. AltaMira Press, Lanham, USA.

Boing L, Stancik MA. 2013. Benzedeiras e benzimentos: práticas e representações no município de Ivaiporã-ParanáBrasil. Ateliê de História 1:85-96.

Brasil. 1990. Lei n. 8.069, Estatuto da Criança e do Adolescente. http://www.planalto.gov.br/ccivil_03/Leis/L8069.htm (Accessed 08/11/2021). 
Cavalli-Sforza LL, Feldman MW, Chen KH, Dornbuscch SM. 1982. Theory and observation in cultural transmission. Science 218 (1):19-27

Clarindo MF, Strachulski J, Floriani N. 2019. Curandeiros Parintintin e benzedeiras: reprodução do saber popular de cura. Hygeia - Revista Brasileira de Geografia Médica e da Saúde 15 (31):105-124

Cunningham AB. 2001. People, wild plant use and Conservation. Applied Ethnobotany, London, U.K.

Dias LG. 2009. "O que é que eu côso?": uma etnografia sobre benzedeiras e benzeduras da Lagoa da Conceição, Florianópolis, Santa Catarina-Brasil. Monography, Federal University of Santa Catarina.

Dias LG. 2013. O poder na e da voz delas: benzedeiras da Itha de Florianópolis, Santa Catarina-Brasil.Master 's thesis, Federal University of Santa Catarina.

Fonseca-Kruel VS, Peixoto AL. 2004. Etnobotânica Reserva Extrativista Marinha de Arraial do Cabo, Rio de JaneiroBrasil. Acta Botanica Brasilica 18:177-190

Geleski FS. 2014. Benzedeiras na Ilha de Santa Catarina a partir da perspectiva de Oswaldo Rodrigues Cabral. Revista Santa Catarina em História 8(1):150-162.

Gill LA. 2010. Benzedeiros Em Pelotas (RS): entre o dom, a tradição e a religião. Anais X Encontro Estadual de História, Federal University of Pelotas.

Hoffmann-Horochovski MT. 2012. Velhas Benzedeiras. Revista de Ciências Sociais 17(2):126-140.

IBGE, Instituto Brasileiro de Geografia e Estatística. 2010. Infográficos: dados gerais do município de Florianópolis, Santa Catarina -Brasil. https://cidades.ibge.gov.br/painel/painel.php?codmun=420540(Accessed 24/06/2021)

Klein RM. 1978. Flora ilustrada catarinense: mapa fitogeográfico do Estado de Santa Catarina. Herbário Barbosa Rodrigues, V Parte - mapa fitogeográfico, Itajaí, Brazil.

Lorenzi H, Matos FJA. 2008. Plantas Medicinais no Brasil: nativas e exóticas. Instituto Plantarum, Nova Odessa, Brazil.

Lozada M, Ladio A, Weigandt, M. 2006. Cultural transmission of ethnobotanical knowledge in a rural community of northwestern Patagonia, Argentina. Economic Botany 60: 374-378.

Maciel MRA, Guarim Neto G. 2006. Um olhar sobre as benzedeiras de Juruena (Mato Grosso, Brasil) e as plantas usadas para benzer e curar. Boletim do Museu Paraense Emílio Goeldi 1:61-77.

Magalhães SM. 2004. Alimentação, saúde e doenças em Goiás no século XIX. Doctoral Thesis, Universidade Estadual Paulista Júlio de Mesquita Filho.

Maluf SW. 1992. Bruxas e bruxarias na Lagoa da Conceição: um estudo sobre representações de poder feminino na Itha de Santa Catarina. Revista crítica de Ciências Sociais 34:99-112.

Moura ECD. 2001. Eu te benzo, eu te livro, te curo: nas teias do ritual de benzeção. Revista de Humanidades 29(11):340-369.

Oliveira ER. 1985. O que é benzeção. Editora brasiliense, São Paulo, Brazil.

Oliveira ECS, Trovão, DMBM. 2009. O uso de plantas rituais de rezas e benzeduras: um olhar sobre esta prática no estado da Paraíba. Revista Brasileira de Biociências 7(3):245-251.

Oliveira EP, Taques EM, Moreira PVS, Sieben CR, Lorenzetti ER. 2016. Plantas medicinais empregadas em desenvolvimento na Região de Palmas, Paraná-Brasil. Cadernos de Agroecologia 11(2).

Pagnocca TS, Zank S, Hanazaki N. 2020. "The plants have axé": investigating the use of plants in Afro-Brazilian religions of Santa Catarina Island. Journal of Ethnobiology and Ethnomedicine 16(20):1-13.

Reyes-García V, Gallois S, Demps KA. 2016. Multistage learning model for cultural transmission: evidence from three indigenous societies. In: Terashima H., Hewlett B. (eds) Social Learning and Innovation in Contemporary HunterGatherers. Replacement of Neanderthals by Modern Humans Series. Springer, Tokyo.

Santoro FR, Chaves LS, Albuquerque UP. 2020. Evolutionary aspects that guide the cultural transmission pathways in a local medical system in Northeast Brazil. Heliyon 6:e04109 doi: 10.1016/j.heliyon.2020.e04109

Silva MAS. 2016. Cultura Açoriana no contexto da cidade-mercadoria: da invisibilidade à mercantilização Florianópolis/SC. Caminhos de Geografia 17: 144-161.

Siuda-Ambroziak R. 2018. Benzedeiras em vias de extinção na Ilha da Magia. Métis: História \& Cultura 34 (17):125146.

Soares MS. 2001. Médicos e mezinheiros na corte imperial: uma herança colonial. História, Ciências, Saúde 8 (2):407438 
Sousa MC, Queiroz GS, Morais MGG, Albuquerque LTC, Malheiro DR, Oliveira CDM. 2021. Cura pela fé: as benzedeiras do Cariri Cearense/Healing by faith: the benzedeiras de Cariri Cearense. Revista Multidisciplinar e de Psicologia 15(54):323-332.

Van-Andel TR, Ruysschaert S, Putte KV. 2013. What makes a plant magic? Symbolism and sacred herbs in afrosurinamese rituals. In African Ethnobotany in the Americas. Edited by R Voeks, J Rashford. Springer, New York, Pp. 247-284.

Zank S, Hanazaki N. 2012. Exploring the links between ethnobotany, local therapeutic practices, and protected areas in Santa Catarina coastline - Brazil. Evidence-based Complementary and Alternative Medicine 1-15.

Zank S, Hanazaki N. 2016. Healing faith: knowledge, learning and social relationships of healers from Araripe plateau - Brazil. Ethnobiology and Conservation 5:1-15.

Zank S, Hanazaki N. 2017. The coexistence of traditional medicine and biomedicine: A study with local health experts in two Brazilian regions. PloS one 12(4):1-17. 